\title{
EVALUASI PELAKSANAAN KURIKULUM 2013 DALAM MATA PELAJARAN PENDIDIKAN AGAMA BUDDHA DAN BUDIPEKERTI
}

\author{
Hesti Sadtyadi \\ STAB Negeri Raden Wijaya Wonogiri Jawa Tengah \\ 15hestisadtyadi@gmail.com
}

\begin{abstract}
ABSTRAK
Penelitian ini bertujuan untuk mengetahui bagaimana proses, dan output dalam penerapan kurikulum 2013 pendidikan agama Buddha pada pendidikan dasar dan menengah. Penelitian ini merupakan penelitian evaluasi, dengan model evaluasi program CIPP. Hasil dari penelitian ini menunjukkan bahwa proses pendidikan agama Buddha pada pendidikan dasar dan menengah, dalam penerapan kurikulum 2013, telah berjalan cukup baik. Output pendidikan agama Buddha dan Budi pekerti, pada tingkat dasar dan menengah, dalam penerapan kurikulum 2013, telah memiliki kuantitas capaian tujuan (output) pembelajaran ketercapaian nilai yang baik. Semua siswa dalam belajar berhasil dengan baik. Kualitas capaian tujuan (product), dilihat tentang perkembangan kondisi sikap dan minat siswa terhadap mata pelajaran, juga kemampuan siswa dalam menerapkan dan praktik beragama dalam kesehariannya. Siswa telah bersikap positif.
\end{abstract}

Kata Kunci : Evaluasi Kurikulum Pendidikan Agama Buddha

\begin{abstract}
This study aims to find out how the process, and output in applying the curriculum 2013 of Buddhist education in primary and secondary education. This research is an evaluation research, with the CIPP program evaluation model. The results of this study indicate that the process of Buddhist education in primary and secondary education, in the application of the curriculum 2013, has gone quite well. The output of Buddhist and moral education, at the primary and secondary levels, in applying the 2013 curriculum, has had a quantity of good learning outcomes. All students in learning succeed well. The quality of the achievement of objectives (product), seen from the development of the condition of students' attitudes and interests towards the subject, also the ability of students to implement and practice religion in their daily lives. Students have been positive.
\end{abstract}

Keywords: Evaluation of Buddhist Education Curriculum

1 Asosiasi Dosen Raden Wijaya dan \& Unit Penelitian dan Pengabdian Masyarakat 


\section{Pendahuluan}

Pendidikan agama Buddha, di pendidikan dasar dan menengah, telah menerapkan kurikulum 2013. Dalam penjelasan dari struktur Kurikulum 2013, bahwa struktur kurikulum menggambarkan konseptualisasi konten kurikulum dalam bentuk mata pelajaran, posisi konten/mata pelajaran dalam kurikulum, distribusi konten/mata pelajaran dalam semester atau tahun, beban belajar untuk mata pelajaran dan beban belajar per minggu untuk setiap peserta didik. Struktur kurikulum adalah juga merupakan aplikasi konsep pengorganisasian konten dalam sistem belajar dan pengorganisasian beban belajar dalam sistem pembelajaran. Pengorganisasian konten dalam sistem belajar yang digunakan untuk kurikulum yang akan datang adalah sistem semester sedangkan pengorganisasian beban belajar dalam sistem pembelajaran berdasarkan jam pelajaran per semester.

Dalam pelaksanaan pendidikan agama Buddha, seperti data hasil penelitian sebelumnya (Sadtyadi, 2018 dan 2019), menunjukkan bahwa guru pendidikan agama Buddha, memiliki ketimpangan baik dalam prasarana dan sarana, dalam mendukung pelaksanaan pembelajarannya. Guru dalam melaksanakan pembelajaran belum tentu dapat dilakukan di ruang kelas, tetapi penyelengaraanya dilakukan di ruang yang lain, seperti perpustakaan, ataupun ruang lainnya, seperti ruang bimbingan. Pelaksanaan dapat dilakukan di dalam ruang kelas, tetapi proses pembelajaran dilakukan diluar jam belajar, atau setelah jam belajar.
Sarana pendukung yang dipergunakan secara umum, sudah terpenuhi, tetapi terdapat permasalahan-permasalahan, seperti pada saat awal penerapan kurikulum 2013, terdapat masalah dengan buku sebagai bahan ajar, yang sulit diperoleh, dan berada dalam bentuk soft copy, sehingga, jangkauan untuk siswa maupun guru, yang berada dalam lokasi yang terpencil memiliki kendala dalam hal mendapatkannya.

Guru dalam pelaksanaan tugasnya (Sadtyadi, 2014), yang terbagi dalam tugas pokok dan fungsinya, seperti, mengajar, membimbing, mendidik, melatih, maupun menilai dan mengevaluasi. Dalam hal tupoksi menilai dan mengevaluasi seperti dalam Peraturan Menteri Pendidikan Nasional Republik Indonesia No. 41 Tahun 2007, yang menyebutkan tentang Standar Proses Untuk Satuan Pendidikan Dasar dan Menengah, disebutkan bahwa penilaian atau evaluasi pembelajaran wajib dilakukan oleh guru terhadap hasil pembelajaran. Kegiatan tersebut dilakukan untuk mengukur tingkat pencapaian kompetensi peserta didik, serta digunakan sebagai bahan penyusunan laporan kemajuan hasil belajar, dan memperbaiki proses pembelajaran (Aqib, 2009: 129).

Kondisi yang telah dilakukan untuk pendidikan agama Buddha, yang merupakan bagian dari satu mata pelajaran yang ada di tingkat sekolah dasar, dan menengah, dengan program menerapkan kurikulum 2013. Keterlaksanaan kurikulum tidak akan dapat dilepaskan dengan input, proses pelaksanaan, dan hasil capaian atau output dari proses pelaksanaan kurikulum tersebut. Penelitian ini 
Jurnal Pendidikan, Sains Sosial dan Agama

merupakan penelitian evaluasi, yang akan berusaha menemukan kelemahan, kekuatan, pelaksanaan kurikulum 2013 pada pendidikan agama Buddha, dengan pengkajian silang pada proses dan output.

\section{Metode Penelitian evaluasi}

Jenis penelitian ini merupakan penelitian evaluasi, dengan model evaluasi program CIPP. Metodologi Evaluasi yang digunakan dalam penelitian ini lebih memiliki kecenderungan mempergunakan evaluasi Kualitatif, dimaksudkan dengan evaluasi kualitatif dapat dilakukan untuk mencari 'kualitas' dari input, proses, dan output, dari suatu program, dengan batasan pembahasan yang difokuskan pada bagian proses dan outputnya, dengan cakupan yang luas, beragam, dan teliti sesuai dengan fakta, dengan tidak menanggalkan data yang bersifat kuantitatif, yang dapat digunakan dalam membantu analisis dan memvalidasi data lebih lanjut.

\section{Hasil Penelitian}

\section{Proses}

Process, yaitu proses pelaksanaan pembelajaran pendidikan agama Buddha, dilihat dalam: menerapkan materi/bahan ajarnya. Guru pendidikan agama Buddha, sesuai dengan petunjuk dan ketentuan di sekolah tempat tugas guru mengajar, sebagian besar telah menerapkan kurikulum 2013. Pelaksanaan proses belajar siswa, dalam pendidikan agama Buddha, telah sesuai dengan perencanaan pembelajaran yang telah disiapkan oleh guru pendidikan agama Buddha. Berdasarkan data observasi dan wawancara, serta data keterlaksanaan UASBN,

menunjukkan bahwa, sebagian besar satuan pendidikan telah melaksanakan kurikulum 2013, tetapi ada sebagian yang belum melaksanakan kurikulum 2013. Pelaksanaan kurikulum 2013, pada satuan pendidikan yang belum menjalankan kurikulum 2013, tidak berarti secara totalitas seluruh kelas belum melaksanakan kurikulum tersebut, tetapi terbagi, beberapa kelas diantaranya telah diterapkan kurikulum 2013. Sebagai contoh di kelas IX, SLTP terdapat sebagian belum menerapkan kurikulum 2013, tetapi masih KTSP, tetapi untuk kelas VII dan VIII, telah menerapkan kurikulum 2013. Kondisi ini dilatar belakangi atas kesiapan dan analisis secara internal satuan pendidikan tersebut.

Berdasarkan kebijakan pelaksanaan kurikulum 2013 dan KTSP, menjadikan evaluasi keterlaksanaan kurikulum 2013 tersebut, menggunakan dua model instrumen penilaian yang berbeda, sehingga belum menghasilkan gambaran yang sama antar satuan pendidikan baik dari SD, SLTP dan SLTA. Berdasarkan data observasi dan wawancara, dengan memperhatikan dokumen di lapangan menunjukkan bahwa guru pendidikan agama Buddha di Satuan pendidikan yang telah menerapkan kurilulum 2013, telah berupaya untuk menerapkan strategi/metodenya pembelajaran, sesuai dengan tahapan yang diharapkan dalam kurikulum 2013, seperti dengan memperguanakan metode Scientifik. Demikian pula dalam menerapkan medianya, dan menerapkan evaluasinya, yang telah dilakukan penyesuaian secara bertahap dan berkesinambungan. 


\section{Produk/ Output}

Product, yaitu kualitas hasil capaian tujuan dari pelaksanaan program pembelajaran pendidikan agama Buddha, dilihat dari (a) output (kuantitas) memperhatikan sejumlah hasil dari proses pendidikan dengan mempergunakan kruikulum 2013, dapat disampaikan bahwa keterlaksanaan kurikulum 2013, berjalan sesuai standar yang ada, dengan kata lain memiliki ketercukupan keterlaksanaanya. Semua satuan pendidikan telah menjalankan UASBN pendidikan agama Buddha, dengan rata-rata perolehan nilai cukup baik, sampai dengan sangat baik.

Kondisi kuntitas capaian hasil belajar siswa pendidikan agama Buddha, dapat dijelaskan dari rata-rata nilai yang dimiliki siswa sebagai keberhasilan belajar dengan mempergunakan kurikulum 2013, dapat dikatakan memiliki keberhasilan yang memuaskan. Hal ini tampak dari hasil nilai yang mampu mencapai nilai secara umum diatas 70 (sumber data peneliti).

Nilai hasil studi siswa pada matapelajaran pendidikan agama Buddha dan Budi pekerti, yang di dalamnya terdapat nilai-nilai sikap, yang menghasilkan nilai baik sampai dengan baik sekali. Nilai sikap tercermin pada hasil nilai yang dapat diklasifikasikan dalam kategori berikut : Sebagian siswa telah terus menerus memperlihatkan perilaku Menghayati dan Mengamalkan ajaran beragama, sebagian siswa telah mengembangkan perilaku jujur, disiplin, tanggung jawab, peduli, santun, ramah lingkungan, gotong royong, kerjasama, cinta damai, responsif dan kreatif, dan menunjukkan sikap sebagai bagian dari solusi atas berbagai permasalahan bangsa dalam berinteraksi secara efektif dengan lingkungan sosial dan alam serta dalam menempatkan diri sebagai cerminan bangsa dalam pergaulan dunia dengan gambaran sudah memperlihatkan berbagai tanda perilaku tersebut, dan sebagian kecil mulai terlihat adanya tanda-tanda awal perilaku yang dinyatakan dalam indikator tersebut tetapi belum konsisten, atau belum diteruskan secara terus menerus.

\section{Kualitas Capaian Nilai-nilai Karakter Beragama dalam Mata Pelajaran Pendidikan Agama Buddha dan Budhi Pekerti.}

Kualitas capaian nilai sikap dalam mata pelajaran pendidikan agama Buddha dan Budhi Pekerti, dihasilkan diantaranya dari gambaran sikap siswa terhadap Agama Buddha dan Budipekerti, yang juga menunjukkan gambaran adanya minat siswa dalam belajar, yang menunjukkan pula sebagai capaian nilai-nilai sikapnya. Data diperoleh dengan mempergunakan instrument tentang sikap.

Aktivitas kegiatan siswa dalam belajar pendidikan agama Buddha dan Budipekerti, kurikulum 2013, dengan tahapan seperti disarankan dalam buku guru, dengan mempergunakan scientifik, dengan dipergunakan asesmen otentik.

Observasi di lapangan dilakukan dalam upaya memperoleh data tentang sikap yang dimiliki siswa. Hasil pengamatan menunjukkan bahwa: (1) respon siswa cukup baik terhadap 
Jurnal Pendidikan, Sains Sosial dan Agama

pelajaran pendidikan agama Buddha dan budipekerti kurikulum 2013. (2) Siswa memiliki penilaian yang positif terhadap mata pelajaran pendidikan agama Buddha, yang menunjukkan bahwa mata pelajaran pendidikan agama Buddha penting dan diperlukan; (3) Siswa memahami bahwa mata pelajaran pendidikan agama Buddha dan Budipekerti, memiliki peran penting dalam mengembangkan dan membangun sikap jujur, disiplin dan lainnya, sebagai sikap positip siswa bergama Buddha.

Guru Pendidikan Agama Buddha dan Budipekerti pada umumnya menyatakan puas terhadap prestasi yang dapat diraih siswanya dalam belajar, dan dapat disampaikan bahwa capaian hasil belajar pendidikan agama Buddha sudah sesuai dengan harapan atau memiliki kualitas yang baik. Sekalipun demikian masih tetap berupaya memotivasi dan lebih meningkatkan prestasinya.

\section{Manfaat Capaian Nilai-nilai Keagamaan dalam Pendidikan Agama Buddha dan Budipekerti}

Manfaat capaian tujuan pembelajaran pendidikan agama Buddha dan Budipekerti, di sebagian siswa pendidikan agama Buddha yang diteliti terlihat dari:(a) kemampuan yang berkaitan dengan kemampuan siswanya dalam kompetensi baik secara kognitif, sikap maupun ketrampilannya, sekaligus terkait dengan karakter keagamaanya.

\section{Pembahasan}

\section{Context}

Deskripsi tentang kondisi karakteristik guru dalam menunjang proses pembelajaran mata pelajaran pendidikan agama Buddha, di satuan pendidikan di Jawa Tengah, meliputi tiga

Analisis data disajikan dalam empat bagian yaitu : context, input, process, dan product. Berkaitan dengan konteks dalam penelitian ini disampaikan hal-hal sebagai berikut. context membahas tentang guru, dan satuan pendidikan (sekolah) sebagai pendukung proses pembelajaran, meliputi: (1) kondisi guru, dilihat dari latar belakang pendidikan, pengalaman, status kepegawaian, dan profesionalisme dalam mengajarkan mata pelajaran pendidikan agama Buddha ataupun yang terkait dengan hal tersebut; dan (2) kondisi Satuan pendidikan (Sekolah), dilihat dari fasilitas, kondisi fisik dan lingkungannya. Bagian kedua adalah input, membahas tentang pengembangan bahan dan fasilitas penunjang program pembelajaran, meliputi: (1) pengembangan silabus dan perencanaan pembelajaran terkait kurikulum 2013, dan (2) pengembangan materi pembelajaran. Bagian ketiga adalah process, membahas tentang pelaksanaan program, meliputi: (1) penerapan materi/bahan ajar, (2) penerapan strategi/ metode, (3) penerapan media, dan (4) penerapan evaluasi, serta peran guru. Bagian keempat adalah product, membahas tentang capaian tujuan program, meliputi: (1) kuantitas capaian (output); (2) kualitas capaian (product), dan (3) manfaat capaian (outcome) pembelajaran pendidikan agama Buddha dan Budipekerti. 
Jurnal Pendidikan, Sains Sosial dan Agama

dimensi, yaitu (1) latar belakang pendidikan dan pengalaman, (2) status kepegawaian, dan (3) kompetensi guru dalam mengajarkan mata pelajaran pendidikan agama Buddha yang mengimplementasikan pendidikan agama dan budipekerti. (4) kondisi satuan pendidikan yang mengimplementasikan kurikulum 2013 pendidikan agama Buddha dan Budipekerti.

a. Latar Belakang Pendidikan Guru, dan Status Kepegawaian

Guru mata pelajaran pendididkan agama Buddha secara umum telah menyelesaikan pendidikan strata satu dan sebagian strata dua (S2), sesuai dengan bidang yang ditugaskan. Guru mata pelajaran pendidikan agama Buddha merupakan alumni dari STAB baik negeri dan swasta yang ada di Indonesia. Pengalaman mengajar guru, dimiliki sejak tahun pengangkatan, terdapat sejumlah guru dengan pengangkatan dari dinas pendidikan dan dari kementerian agama. Pengalaman kerja terlama guru pendidikan agama Buddha berkisar 30 tahun, dengan masa kerja terendah 3 tahun. Selain itu guru pendidikan agama Buddha dan budipekerti merupakan guru dengan status PNS dari kementerian agama yang diperbantukan, dan guru PNS kementerian pendidikan dan kebudayaan, serta guru tidak tetap (GTT).

b. Kompetensi Guru di bidang Mata Pelajaran Pendidikan Agama Buddha dan Budipekerti sebagai pelaksana kurikulum 2013.

Guru pendidikan agama Buddha, telah memiliki kompetensi yang memadai. Hal ini ditandai bahwa guru tersebut telah memiliki pengalaman kerja yang cukup, tetapi kebanyakan guru belum tersertifikasi. Berdasarkan kinerjanya, dalam menjalankan tugas poko dan fungsi keguruannya, telah melakukan pekerjaan keguruanyya yang dilakukan dengan baik. Hal ini dapat dilihat dari beberapa indikator yang dimilikinya dalam menjalankan tugas, seperti (1) kemampuan guru dalam merancang silabus berdasarkan tujuan dan kebutuhan, (2) kesiapan guru dalam menempatkan dan menjadi model bagi siswa, (3) kemampuan guru dalam merancang pengalaman belajar bagi siswanya; kemampuan guru dalam mengelola proses pembelajarannya dalam kelas (memilih materi,metode, media, dan evaluasi); (5) keaktifan guru dalam membaca dan literatur utama dan penujang mata pelajaran agama Buddha dan Budipekerti; (6) keaktifan guru dalam membaca buku-buku penunjang profesi; (7) keterbukaan guru dalam berkomunikasi dengan siswa; dan (9) kelengkapan koleksi kumpulan materi pembelajaran yang dimiliki. (10). Keikutsertaan guru dalam organisasi profesi.

Berdasarkan hasil observasi, wawancara dan dokumen yang tersedia, menunjukkan bahwa guru secara umum telah memiliki cukup kompetensi dalam menjalankan tugas pokok dan fungsinya. Berikut pernyataan yang disampaikan oleh seorang guru pendidikan agama Buddha dari wilayah Slogohimo dalam salah satu bagian penyusunan silabus yang pernah dilakukannya,bahwa 
"Fokus tujuan pembelajaran dalam mata pelajaran pendidikan agama Buddha dituangkan dengan menyusun mulai dari rencana pembelajaran sampai dengan ...pembelajaran yang mencakup competence, conscience, dan compassion ..., silabus yang linier dengan kurikulumnya yakni kurikulum 2013 (sumber hasil wawancara).

Hal ini nampak bahwa suasana, untuk guru mendukung dalam proses pembelajaran. Pelaksanaan untuk keadaan tersebut sudah terdukung dengan cukup baik, sehingga nilainilai yang harus dicapai dalam pendidikan agama Buddha dapat diterapkan sebagai bagian dari hasil belajarnya.

c. Kondisi Secara Umum Sekolah Tempat Mengajar Pendidikan Agama Buddha

Deskripsi tentang kondisi karakteristik kampus dan lingkungannya dalam mendukung proses pembelajaran mata pelajaran pendidikan agama Buddha dan Budipekerti, ditinjau dari dua dimensi, yaitu: (1) kondisi fasilitas sarana/ prasarana sekolah dan (2) kondisi lingkungan dalam mendukung proses pembelajaranya.

1) Kondisi fasilitas sarana prasarana sekolah.

Kondisi fasilitas sarana dan prasarana di sekolah, tempat tugas Bapak/Ibu guru pendidikan agama Buddha dalam pelaksanaan pembelajaran pendidikan agama Buddha dan Budipekerti, dilihat dari aspek berikut: (1) kemudahan memperoleh bahan ajar; (2) ketersediaan media pembelajaran yang menunjang pembelajaran; dan (3) Prasarana yang tersedia.

Berdasarkan data bahwa buku guru untuk mata pelajaran pendidikan agama Buddha yang tersedia, diambil melalui media on line, sehingga memperoleh buku guru dan buku siswa, tetapi masih dalam bentik soft copy. Pada umumnya guru memperoleh hard copy melalui kerjasama bersama dalam KKG dan atau MGMP setempat (data wawancara dengan guru dalam KKG, di Semarang). Sedangkan ketersediaan media pembelajaran yang diberikan cukup memadai, guru secara umum masih mempergunakan papan sebagai media, ditambah dengan kreatifitas, dengan mengembangkan kemampuan diri.

Ruang tempat belajar yang disediakan bagi mata pelajaran pendidikan agama Buddha dan Budipekerti pada umumnya mempergunakan bukan ruang kelas, tetapi ruang yang dapat digunakan untuk belajar, seperti perpustakaan, ruang Bimbingan, atau ruang kelas, jika waktu belajar yang digunakan diluar jam mengajar, atau setelah siswa pulang sekolah.

2) Kondisi lingkungan dalam mendukung proses pembelajaran.

Lingkungan sekolah tempat siswa belajar dengan didampingi guru pendidikan agama Buddha, secara umum sangat mendukung, walaupun sarana prasarana yang dimiliki dengan keterbatasannya. Wujud fasilitas lainnya berupa sarana olah raga, seni musik, dan atau karawitan, maupun penunjang lainnya. 


\section{Input}

Deskripsi tentang pengembangan bahan dan fasilitas penunjang pelaksanaan pembelajaran mata pelajaran pendidikan agama Buddha dan Budipekerti yang meliputi dua dimensi, yaitu Silabus dan perencanaan pembelajaran, dan materi/ bahan ajar (Buku Guru dan Buku Siswa).

a. Silabus dan perencanaan pembelajaran

Silabus, yang merupakan bagian yang tidak terpisahkan dari kurikulum, dirumuskan, dibuat dan telah ditetapkan oleh satuan pendidikan yang akan melaksanakannya. Dalam silabus telah disesuaikan dengan kurikulum dan kebutuhan serta sesuai dengan perkembangan yang ada. Dalam silabus tersebut memuat deskriptor-deskriptor yang menjelaskan kemampuan di bidang, sesuai dengan tujuan pembelajaran yang akan dicapainya.

Learning outcomes dalam perencanaan pembelajaran (RPP), merupakan internalisasi dan akumulasi ilmu pengetahuan, ketrampilan, afeksi, dan kompetensi yang dicapai melalui proses pendidikan yang terstruktur dan mencakup bidang pendidikan agama Buddha, baik untuk siswa SD, SMP dan SLTA, seperti tertuang dalam pedoman kurikulum 2013, khususnya untuk pendidikan agama Buddha dan Budipekerti.

Penyusunan RPP atau rencana pembelajaran yang dilakukan guru pendidikan agama Buddha dan Budipkerti, di lingkungan guru pendidikan agama Buddha, dilakukan dalam KKG dan atau MGMP secara bersamasama. Organisasi tersebut melakukan koordinasi dan bimbingan teknis dengan sejumlah guru, dan pejabat terkait.

\section{b. Materi/Bahan Ajar.}

Materi pembelajaran dilakukan oleh guru mata pelajaran pendidikan agama Buddha tersebut. Bahan ajar yang digunakan mengacu pada kurikulum dan silabus yang telah ditetapkan, yang merujuk pada buku guru untuk pegangan guru dan buku siswa, sebagai buku pegangan untuk siswa didik.

Buku guru maupun buku siswa, memiliki kendala dalam hal buku cetak, guru pendidikan agama Buddha, mendapatkan sumber buku dari soft copy, yang diambil melalui internet yang tersedia, dan dicetak secara mandiri. Dalam Buku Guru dan Buku siswa masih terdapat kendala yang dihadapi dalam pemakaiannya yakni, masih terdapat kesalahan dalam hal beberapa materi, terdapat kesalahan tulis atau cetak, dan ketidak sesuaian gambar sebagai sumber belajar.

\section{Proses}

Proses pembelajaran mata pelajaran pendidikan agama Buddha, untuk siswa beragama agama Buddha, pada satuan pendidikan SD, SMP dan SLTA, di Jawa Tengah, dapat didiskripsikan dalam komponen yaitu menerapkan materi/bahan ajar, menerapankan strategi/metode, menerapkan media dan menerapkan evaluasi. Analisis dilakukan dengan memperhatikan peran guru dan siswa dalam proses belajar.

a. Menerapkan materi/ bahan Ajar 
Jurnal Pendidikan, Sains Sosial dan Agama

Guru pendidikan agama Buddha, dalam mengampu mata pelajaran pendidikan agama Buddha dan Budipekerti, dapat dilihat dari kreatifitas dalam berbagai kegiatan pembelajaran yang menjadi tugasnya. Pelaksanaan proses pembelajaran bagi guru dalam kelas tampak bahwa guru telah melakukan aktivitas dengan antusias. Guru mempergunakan buku guru sebagai bagian sumber utama dalam proses belajar dan pengembangan materinya.

\section{b. Menerapkan metode/Strategi}

$$
\text { Pendidikan agama Buddha dan }
$$

Budipekerti, merupakan proses yang sangat panjang karena pendidikan agama Buddha tidak hanya melakukan transfer of value tetapi menanamkan kebiasaan yang baik sampai menjadi karakter individu yang akan turut membentuk identitas pribadi sehingga membutuhkan proses karena dituntut tidak hanya mengetahui, tetapi siswa dapat mengetahui, merasakan dan pada akhirnya melakukan kebiasaan positif sehingga menjadi karakter beragama Buddha yang baik dan benar. Proses pembelajaran di lingkungan Sekolah, khususnya dalam hal mata pelajaran pendidikan agama Buddha, menerapkan berbagai strategi pembelajaran yang dapat mengarahkan dan membantu siswa dalam mencapai tujuan pembelajarannya.

Proses pembelajaran khususnya dalam hal penerapan metode dan strategi pembelajaran di lingkungan Sekolah, menerapkan bentuk-bentuk model tersebut. Strategi pembelajaran yang digunakan dengan bentuk Active learning dengan menggunakan pendekatan intervensi dan habituasi, melalui metode Scientifik, sesuai dengan buku guru yang telah disepakati sebagai sumber utama. Dalam menerapkan strategi/metode pembelajaran, dalam menerapkan intervensi diantaranya dilakukan dengan berbagai strategi pembelajaran active learning, seperti cooperatif learning, pembelajaran berdasarkan masalah, simulasi, inkuiri, dan lain-lainnya. Sedangkan habituasi dilakukan dengan pendemonstrasian berbagai contoh teladan sebagai langkah awal pembiasaan, penguatan dalam berbagai bentuk, penataan lingkungan belajar yang menyentuh dan membangkitkan karakter (Sumber :Peneliti). Prinsip pembelajaran active learning yang digunakan dalam pengembangan pendidikan karakter mengusahakan agar siswa mengenal dan menerima nilai-nilai agama sesuai kompetensi inti yang akan menjadi bagian yang dicapai dalam pembelajarannya.

Pelaksanaan strategi pembelajaran aktif ini dilakukan melalui; proses pembelajaran aktif, dengan pendampingan maupun strategi penilaian portofolio. Dalam pembelajaran active learning, sesunguhnya tidak berdiri sendiri, tetapi berproses dengan mata pelajaran yang lain sesuai Kompetensi inti dalam kurikulum 2013. Penerapan dilakukan melalui strategi active learning sehingga satu aktivitas belajar dapat didesain dan digunakan untuk mengembangkan kemampuan dalam ranah pengetahuan, sikap dan ketrampila yang didalamnya mengandung muatan karakter. Dalam proses pembelajaran juga digunakan prinsip belajar aktif dan menyenangkan, artinya prinsip ini juga 
Jurnal Pendidikan, Sains Sosial dan Agama

menyatakan bahwa proses pendidikan dilakukan dalam suasana belajar yang menimbulkan rasa senang dan tidak indoktrinatif.

c. Menerapkan media.

Mata pelajaran pendidikan agama Buddha, sangatlah penting untuk dipelajari karena merupakan bagian yang akan mengajarkan aklak mulia, kejujuran, kedisiplinan dan lainnya yang bersesuaian dengan ciri karakter Bangsa Indonesia. Untuk membantu siswa memperoleh pengetahuan dan keterampilan dan mengembangkan karakternya, perlu dikembangkan dan digunakan media pembelajaran yang sesuai. Media yang dimaksud dapat berupa alat yang sederhana dengan memanfaatkan benda-benda yang tersedia, sesuai dengan kelas, dan jenjang pendidikan yang ditempuhnya. Media yang dipilih guru tidak meninggalkan tema utama, dan dapat bersumber dari buku guru, yang sekaligus dapat mengembangkan karakter positip seperti kejujuran, kedisiplinan dan lainnya.

\section{d. Menerapkan Evaluasi}

Dalam melaksanakan penilaian pembelajaran Mata pelajaran pendidikan agama Buddha dan Budipekerti, berdasarkan data yang dikumpulkan melalui observasi dan wawancara dan pengisian instrumen, dapat disampaikan bahwa model penilaian yang digunakan adalah authentic. Model penilaian ini dianjurkan untuk diterapkan, karena mampu memberikan informasi yang lebih akurat dan baik. Berkaitan dengan teknik dan instrumen penilaian yang dipilih dan dilaksanakan tidak hanya mengukur pencapaian akademik/kognitif siswa, tetapi juga mengukur perkembangan kepribadian siswa. Bahkan perlu diupayakan bahwa teknik penilaian yang diaplikasikan dapat dan mampu mengembangkan kepribadian siswa sekaligus. Bentuk dan model penilaian ini sesuai dengan teknik penilaian dan evaluasi dalam kurikulum 2013.

Teknik-teknik penilaian yang digunakan untuk menilai pencapaian siswa baik dalam hal pencapaian akademik, maupun sikap dan kerampilan, berupa observasi (dengan lembar observasi/lembar pengamatan), penilaian diri (dengan lembar penilaian diri/kuesioner), dan penilaian antarteman (lembar penilaian antarteman (khusus untuk kelas besar SLTA). Nilai sikap siswa dinyatakan secara kualitatif. Nilai siswa menggambarkan perkembangan sikap, pengetahuan dan ketrampilan yang bersangkutan pada saat penilaian dilakukan. Nilai tersebut merupakan dasar bagi guru untuk memberikan pembinaan lebih lanjut agar siswa yang bersangkutan mengembangkan karakternya hingga optimal.

Pihak sekolah sebagai unit yang bertanggung jawab keterlaksanaan program belajar, melakukan monitoring dan pengawasan, selain melakukan penilaian, yang dilakukan dalam proses pembelajaran, kegiatan pembinaan siswa, maupun manajemennya juga dilakukan monitoring dan dievaluasi setidak-tidaknya setahun sekali. Tujuan umum dari kegiatan ini antara lain adalah untuk mengetahui: 
1. Kesesuaian pelaksanaan pendidikan mata pelajaran dengan ketercapaian standar yang diharapkan,

2. Hambatan-hambatan yang dihadapi dalam pelaksanaannya, dan solusi yang perlu diupayakan, serta hal-hal yang mendukung pelaksanaannya,

3. Perubahan-perubahan yang dilakukan selama pelaksanaan pembelajaran,

4. Tingkat ketercapaian dari target-target pendidikan yang telah dirumuskan, dan

5. Praktik-praktik yang baik dalam tingkat ketercapaian dari target-target mata pelajaran yang telah dirumuskan.

Pelaksanaan monitoring dan evaluasi dibuat panduan singkat yang setidak-tidaknya memuat tujuan, sasaran, komponen/aspek yang dimonitor dan dievaluasi, waktu pelaksanaan, pelaksana, instrumen pengumpul data, dan teknis analisis data.

\section{Produk}

a. Kuantitas Capaian Tujuan (Output) Pembelajaran

Semua Siswa di yang diteliti tuntas dalam belajar mata pelajaran pendidikan agama Buddha dan budipekerti. Dalam proses penilaian yang dilakukan guru ketuntasan diperoleh dari penilaian berdasarkan tugas-tugas, kedisiplinan, keaktifan, ujian tengah semester, ujian akhir semester, sampai dengan UASBN. Penilaian mempergunakan asesmen otentik. Penilaian menghasilkan penilaian kelulusan terhadap mata pelajaran tersebut. Nilai hasil studi siswa untuk mata mata pelajaran pendidikan agama Buddha, yang diteliti, berkisar antara 60 - 97, dalam skala $10-100$.

\section{b. Kualitas Capaian Tujuan (Product)}

Kualitas capaian tujuan pembelajaran mata pelajaran ini dapat dilihat dari sikap dan hasil penilaian dengan mempergunakan asesmen otentik seperti dalam petunjuk kurikulum 2013. Perkembangan Siswa, tampak dari bersikap dan berperilaku seperti indikator berkarakter beragama.

\section{c. Manfaat Capaian Tujuan (Outcome) Pembelajaran}

Capaian kompetensi belajar pada mata pelajaran ini, antara lain terbentuknya keperilakukan positip sesuai dengan indikator karakter dalam mata pelajaran sesuai dengan kompetensi inti yang diharapkan. Capaian tersebut tercermin dari kemampuan siswa dalam mengembangkan wawasan, memahami nilainilai kehidupan, menemukan jati diri, dan bersikap positif dalam menghadapi lingkungan serta realitas kehidupan, sesuai dengan karakter beragama.

\section{Temuan Hasil Penelitian}

Berdasarkan hasil analisis data menunjukkan bahwa pelaksanaan pendidikan agama Buddha dan Budipekerti, telah berjalan dengan cukup baik. Baik dari sisi proses, dan output atau produk. Proses pembelajaran walaupun telah dikatakan cukup dalam keterlaksanaanya, tetapi masih dalam batasan 
Jurnal Pendidikan, Sains Sosial dan Agama

belum terbiasa, yang berarti guru masih memerlukan pelatihan tambahan. Terdapat proses pembelajaran yang harus ditingkatkan. Kualitas capaian tujuan pembelajaran mata pelajaran dilihat dari sikap dan hasil penilaian dengan mempergunakan asesmen otentik, tampak dari bersikap dan berperilaku telah sesuai indikator berkarakter beragama. Capaian tersebut tercermin dari kemampuan siswa dalam mengembangkan wawasan, memahami nilainilai kehidupan, menemukan jati diri, dan bersikap positif dalam menghadapi lingkungan serta realitas kehidupan, sesuai dengan karakter beragama.

\section{Simpulan}

Berdasarkan analisis secara menyeluruh dengan mempergunakan evaluasi program CIPP, maka dapat disimpulkan :

1. Dalam proses penerapan kurikulum 2013 pendidikan agama Buddha, pada pendidikan dasar dan menengah, telah berjalan cukup baik. Proses pelaksanaan pembelajarannya melalui silabus dan perencanaan pembelajarannya, yang sudah sesuai, proses dilakukan sejalan dengan apa yang telah dirancang pada silabus dan RPP, bahan ajar diadaptasi. Dalam hal materi dan bahan ajar dilakukan dengan jalan mengintegrasikan materi dengan komponen tujuan, yang tertulis secara ekplisit. Memperhatikan Siswa disampaikan adanya minat dan sikap positip Siswa terkait dengan belajar mata pelajaran agama Buddha. 
Jurnal Pendidikan, Sains Sosial dan Agama

\section{DAFTAR PUSTAKA}

Azwar, Saifudin (2016). Kontruksi Test

Kemampuan Kognitif. Pustaka Pelajar, Yogyakarta. (2017). Pengantar Psikologi

Intelegensi. Pustaka Pelajar, Yogyakarta.

Aqib,Z., (2009). Menjadi Guru Profesional Berstandar Nasional. Yrama Widya, Bandung.

Bembenutty, H. (2009). Teaching effectiveness, course evaluation, and academic performance: The role of academic delay of gratification, Jurnal; Jaa, Volume 20, Number 2, pp. 326-355.

Bjkic,D.,Krneta, R.\& Milosevic,D. (2010). Teacher education from e-learner to eteacher: Master curriculum, TOJIET:

The Turkish Online Journal of Educational Technology- Januari 2010,V9 Issue 1.

Danim, Sudarwan. (2015). Pengembangan Profesi Guru. Prenamedia Grup. Jakarta.

Duckworth, A. L., Quinn, P. D. \& Seligman, M. E.P. (2009). Positive predictors of teacher effectiveness, The Journal of Positive Psychology, Vol. 4, No. 6, 540547

Sadtyadi, H. (2020). The Analysis Factor of Self-Confidence of Buddhist Religious Teachers in Indonesia. International
Journal of Instruction, Hall. International, Inc.

Sadtyadi, Hesti (2018). Performance assessment and the factors inhibiting the performance of Buddhist education teachers in the teaching duties. Jurnal Reseach and Evaluation in Education. Program Pascasarjana Universitas Negeri Yogyakarta.

Sadtyadi, Hesti. (2014). Tugas Pokok dan Fungsi Guru Sekolah Dasar. Jurnal Penelitian dan Evaluasi Pendidikan. Program Pasca Sarjana Universitas Negeri Yogyakarta.

Karsidi, (2007). MODEL Kurikulum Tingkat Satuan Pendidikan (KTSP) SD dan MI, PT Tiga Serangkai Pustaka Mandiri Solo.

Kementerian Pendidikan dan Kebudayaan; 2013. Kurikulum 2013, Kompetensi Dasar $\mathrm{SD}, \mathrm{MI}$.

Kunandar. (2015). Penilaian Autentik (Penilaian hasil Belajar Peserta Didik Berdasarkan Kurikulum 2013). Rajagrafindo, Jakarta.

Mulyasa, E. (2011). Menjadi Guru Profesional. Remaja Rosdakarya, Bandung.

Nuland, S.V. (2009). Teachers codes; learning from experience. New York: International for Institute for educational planing.

Parkay F.W. \& Stanford, B.H. (2008). Menjadi seorang guru. (Terjemahan Dani 
Jurnal Pendidikan, Sains Sosial dan Agama

Dharyani). Boston: Pearson Education, 75 Arlington Street. (Buku asli diterbitkan tahun 2008).

Parkay F.W. \& Stanford, B.H. (2008). Menjadi seorang guru. (Terjemahan Dani Dharyani). Boston: Pearson Education, 75 Arlington Street. (Buku asli diterbitkan tahun 2008).

Popham, W.,James, (1995). Classroom Assesment, What Teachers Need To Know, University of Calofornia, Los Angeles.

Rachmawati, T., dan Daryanto. (2013). Penilaian kinerja profesi guru dan angka kreditnya. Yogyakarta: Gava Media.

Ramayulis,(2013). Profesi \& Etika Keguruan, Jakarta: Kalam Mulia.

Rasyid,H., \& Mansur, (2009). Penilaian Hasil Belajar. Wacana Prima, Bandung.

Rivai, V., et al. (2008). Performance appraisal; system yang tepat untuk menilai kinerja karyawan dan meningkatkan daya saing perusahaan. Jakarta: PT Raja Grafindo Persada.

Robbins, S. P. (2001). Organizational behaviour. (9 th ed). New Jersey: Prentice Hall. International, Inc.
Rusman, (2018). Manajemen Kurikulum. Rajawali Press. Jakarta

Saud, Udin Syaefudin (2010). Pengembangan Profesi Guru. Alfabeta, Bandung.

Stronge, James H. \& Hindman, Jennifer L. (2006: 6). Teacher performance evaluation. Bedford Country Public School. Handbook Electronic. Diambil tanggal 1 Januari 2012 dari: Http/www.bedford.k12.va.us /teacher/handbook.pdf.

Sudjana, Nana. (2017). Penilaian Hasil Proses Belajar Mengajar. Rosdakarya. Bandung.

Sugiyono. (2019). Metode Penelitian \& Pengembangan. Alfabeta, Bandung.

Widyastono, Herry. (2015). Pengembangan Kurikulum di Era Otonomi Daerah. Bumi Aksara, Jakarta.

Wei, R. C. \& Pecheone, R. L. (2010). Assessment for learning in preservice teacher education. Performance-based assessments. San Francisco: Stanford University, diambil tanggal 28-102012, dari: www.nystce.nesinc.com /PDFs/NY fld090 prepguide.pdf.

Worthen, B. R., \& Sanders, J. R., 1984. Educational evaluation: Theory and practice. Worthington, $\mathrm{OH}$ : Charles A Jones Publishing Company. 
Jurnal Pendidikan, Sains Sosial dan Agama 